\title{
Can the polyculture with South American catfish improve the feeding efficiency of rainbow trout culture?
}

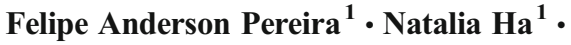 \\ André Fernando Nascimento Gonçalves ${ }^{1}$. \\ Hélio Antunes ${ }^{2} \cdot$ Wagner C. Valenti ${ }^{3}$. \\ Thiago El Hadi Perez Fabregat ${ }^{1}$
}

Received: 3 August 2017 / Accepted: 21 December 2017 / Published online: 29 December 2017

(C) Springer International Publishing AG, part of Springer Nature 2017

\begin{abstract}
The objective of this study was to determine if the South American catfish (Rhamdia quelen) is suitable to be farmed in polyculture with rainbow trout (Oncorhynchus mykiss) in intensive systems during the juvenile phase to maximize feed efficiency. Juveniles of rainbow trout $(3.94 \pm 0.11 \mathrm{~g})$ and South American catfish $(2.07 \pm 0.04 \mathrm{~g})$ were distributed in 16 tanks $(100 \mathrm{~L})$ with continuous water renewal at the density of 50 fish/tank. The experimental design was completely randomized with four treatments (proportions between species) and four replicates. The treatments were $100 \%$ trout $(100 \mathrm{~T}), 70 \%$ trout and $30 \%$ catfish (70T30C), 50\% trout and 50\% catfish (50T50C), and 100\% catfish (100C). Fish were fed
\end{abstract}

Thiago El Hadi Perez Fabregat

thiago.fabregat@udesc.br; thiagofabregat@hotmail.com

Felipe Anderson Pereira

eng.felipeanderson@gmail.com

Natalia Ha

ha.natalia@yahoo.com.br

André Fernando Nascimento Gonçalves

andre@zootecnista.com.br

Hélio Antunes

helio.antunes65@hotmail.com

Wagner C. Valenti

wcvalenti@gmail.com

1 UDESC - Santa Catarina State University, Avenida Luis de Camões, 2090, Lages, SC 88520-000, Brazil

2 Avenida Manoel Bruno, 220, Centro, Urubici, SC 88650-000, Brazil

3 UNESP — São Paulo State University, Aquaculture Center, Via Paulo Donato Castelane s/n, Jaboticabal, SP 14 884-900, Brazil 
twice daily with pelleted commercial feed ( $45 \%$ crude protein) during an experimental period of 56 days. No feed was provided for the catfish in polyculture. The weight gained by the trout was higher in polyculture. Fish survival did not differ among the treatments. The average survival of the trout in all tanks was $99.6 \pm 1.0 \%$, while the survival of the South American catfish was $97.9 \pm 2.7 \%$. The total feed conversion ratio was lower in the $70 \mathrm{~T} 30 \mathrm{~J}$ treatment, followed by the 100T treatment. Rainbow trout and South American catfish are compatible species for farming together in the first phase of their juvenile development. The different spaces occupied by these species inside tanks probably prevent competition or agonistic behavior. Catfish eat the non-ingested leftover diet from the trout, which improves feed conversion and increases sustainability.

Keywords Aquaculture integrated systems - Productive performance - Oncorhynchus mykiss . Rainbow trout $\cdot$ Rhamdia quelen
Abbreviations
C South American catfish
T Rainbow trout
DO Dissolved oxygen
TAN Total ammonia nitrogen
CV Coefficient of variation
WG Individual weight gain
FCR Feed conversion ratio

\section{Introduction}

The South American catfish (Rhamdia quelen) occurs from southeast Mexico to the center of Argentina (Fishbase 2017). Recently, this catfish has been farmed in Brazil and Argentina and has shown good market acceptance (Valladão et al. 2016). Its meat is characterized by good flavor and has no intramuscular spines. The South American catfish has potential for polyculture with trout due to its benthonic habits, adequate growth, tolerance to variations in temperature, and consumption of organic materials (Gomes et al. 2000). Therefore, the objective of this study was to determine if the South American catfish is suitable for farming in polyculture with the rainbow trout in intensive systems during the juvenile phase, to maximize feed efficiency.

\section{Materials and methods}

The study was carried out on a trout farm in the city of Urubici in Southern Brazil $\left(28^{\circ} 03^{\prime}\right.$ $12.6^{\prime \prime} \mathrm{S} 49^{\circ} 34^{\prime} 29.2^{\prime \prime} \mathrm{W}$ ), using real commercial cultivation conditions. The experiment lasted 56 days, which is when the rainbow trout transitions to the grow-out phase. The juveniles of rainbow trout were obtained from the existing brood stock on the property, and juveniles of the catfish from a commercial fish farm near Urubici. The fish were acclimated for 21 days in 300$\mathrm{L}$ tanks with continuous water renovation before the experiment.

After the acclimation period, the juveniles of the rainbow trout $(3.94 \pm 0.11 \mathrm{~g})$ and catfish $(2.07 \pm 0.04 \mathrm{~g})$ were distributed into 16 rectangular tanks $(100 \mathrm{~L})$ with continuous water 
renewal and at a density of 50 fish/tank. The treatments were $100 \%$ trout $(100 \mathrm{~T}), 70 \%$ trout and $30 \%$ catfish (70T30C), 50\% trout and 50\% catfish (50T50C), and 100\% catfish (100C). The experimental design was completely randomized with four treatments (proportions among the species) and four replicates per treatment.

The fish were fed with a pelleted commercial feed ( $45 \%$ crude protein) with a particle size of $3 \mathrm{~mm}$. The feed was offered twice daily until apparent satiation of the trout or catfish in monoculture and of the trout in the polyculture. This management was adopted because trout inhibited the search for food of catfish during the feed supply. We assumed that the fish were satiated when they stop to ingest the pellets. Therefore, in polyculture tanks, the catfish were not fed and were left to eat the leftover diet provided to the trout and their feces. The amount of feed supplied to fish in each tank was recorded. Tanks were cleaned daily after the second feeding to remove organic waste. The water in the tanks was completely renewed every $10 \mathrm{~min}$, and the temperature, $\mathrm{pH}$, and dissolved oxygen were monitored daily. The temperature and dissolved oxygen (DO) were measured with a multiparameter probe, (oximeter AT 160 Alfakit), and the pH was evaluated with a colorimetric kit (Hanna combo HL98129 waterproof). Water samples were collected biweekly to analyze the total ammonia nitrogen (TAN) concentration (Eaton 2005). The temperature $\left(17.3 \pm 1.4^{\circ} \mathrm{C}\right), \mathrm{pH}(7.21 \pm 0.34), \mathrm{DO}(9.50 \pm 0.36 \mathrm{mg} / \mathrm{L})$, and TAN $(0.12 \pm 0.14 \mathrm{mg} / \mathrm{L})$ were kept within the range recommended for rainbow trout culture (Boyd and Tucker 1998; MacIntyre et al. 2008) and were similar in all tanks.

Fish were counted and weighted at the beginning and at the end of the experiment, when they were desensitized with eugenol $(1 \mathrm{~g} / 10 \mathrm{~L})$. The mean individual weight gain, survival, final biomass, and feed conversion rate (FCR) were evaluated. The mean weight gain ( $\mathrm{g}$ ) and survival (\%) were obtained for the two species separately. The biomass (g) was calculated by species and by total fish produced in each tank, using the sum of the individual fish weight. The trout FCR was calculated in each monoculture and polyculture tank because only the trout was fed in polyculture. The total FCR was calculated in each polyculture tank using the sum of biomass gain by the trout and catfish. The following equations were used:

$$
\text { Total FCR }=\frac{\text { Total feed supplied }}{(\text { Total biomass gain by all trout }+ \text { all catfish in the tank })}
$$

Data were subjected to normality (Kolmogorov-Smirnov) and homoscedasticity (Bartlett) tests, followed by the parametric analysis of variance (ANOVA). When significant differences were obtained, the means were compared with Tukey's test $(P<0.05)$.

\section{Results}

Catfish feeding was clearly inhibited by the trout, and only started to feed after the trout ceased feeding. Fish survival did not differ between the treatments. The average survival of the trout in all tanks was $99.6 \pm 1.0 \%$, whereas the survival of the South American catfish was $97.9 \pm$ $2.7 \%$. The weight gained by the trout juveniles was higher in the treatments $70 \mathrm{~T} 30 \mathrm{C}$ and 50T50C when compared to the $100 \mathrm{~T}$ (Table 1). The best results for the trout feed conversion ratio were obtained in the $100 \mathrm{~T}$ and $70 \mathrm{~T} 30 \mathrm{C}$ treatments. The weight gained by the South American catfish juveniles did not differ between treatments. The increase in the proportion of 


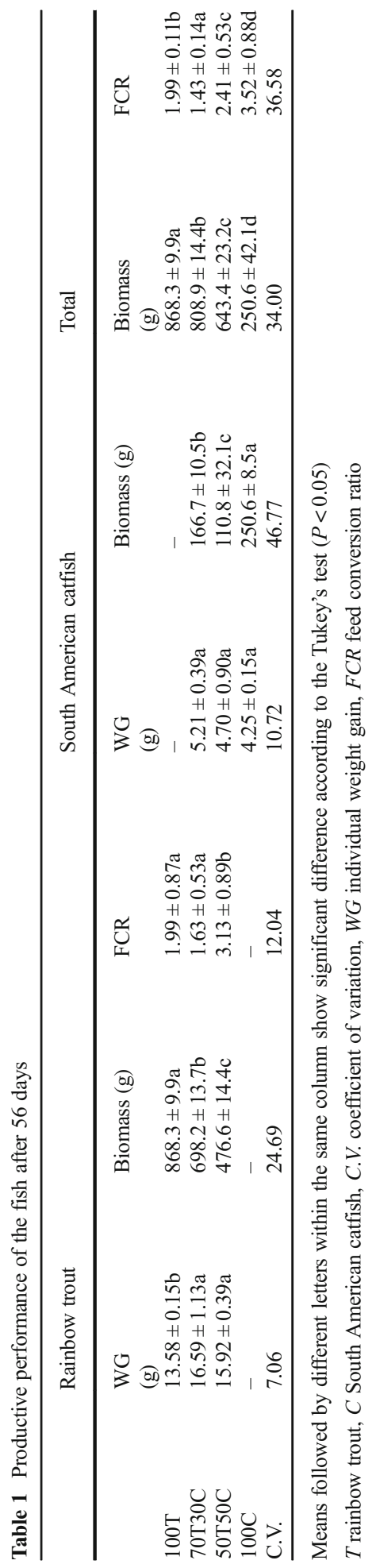


South American catfish juveniles in the culture resulted in a decrease in the total biomass produced. On the other hand, the total feed conversion was better in the 70T30C treatment, followed by the $100 \mathrm{~T}$ treatment. The treatments $50 \mathrm{~T} 50 \mathrm{C}$ and $100 \mathrm{C}$ had the highest total feed conversion ratios.

\section{Discussion}

Survival and growth of each species were not affected by the presence of the other species. The higher weight gain observed in the rainbow trout reared in polyculture is probably because of the lower trout density. Thus, there is no negative interaction between these two species when cultured together in the same tank during the initial stages. Further research should be conducted to demonstrate if no negative interaction occurs for the entire culture cycle.

The polyculture of the rainbow trout with South American catfish improved the total feed conversion rate. This is the first study to show a positive interaction between these two species. Tidwell and Mims (1990) investigated the polyculture of the rainbow trout (95 g) with channel catfish (Ictalurus punctatus) $(82 \mathrm{~g})$ stocked in low $\left(24.7\right.$ catfish and $\left.9.8 \mathrm{trout} / \mathrm{m}^{2}\right)$ and high densities (49.4 catfish and 9.8 trout $/ \mathrm{m}^{2}$ ). The feed conversion ratio increased from 1.3 in trout monoculture to 1.9 in low-density and 2.4 in high-density polyculture. In the referred study, however, the proportion of catfish was higher in relation to the trout, which certainly affects the results. Other polycultures of trout ( $82 \mathrm{~g}$ ) with channel catfish $(240 \mathrm{~g})$ stocked in cages at 300 fish $/ \mathrm{m}^{3}$ compared two species proportions (50\% trout and 50\% catfish; $10 \%$ trout and $90 \%$ catfish) to trout and catfish monoculture (Beem and Gebhart 1988). The feed conversion ratio increased to 2.3 (50\% trout and 50\% catfish) and 9.0 (10\% trout and 90\% catfish) when compared to the trout monoculture.

Trout feed on artificial diets in culture tanks, which can be pelleted or extruded. The pelleted diet is cheaper, but results in higher losses of solids in the water and higher feed conversion ratio (Booth et al. 2000). The South American catfish is a benthic species that accepts feed easily, but also has the potential to feed on organic waste (Gomes et al. 2000). Thus, in polyculture, catfish eat the leftover diet provided to trout and probably trout feces. Survival and growth of the catfish in the present study was similar in fed (monoculture) and unfed scenarios (polyculture), demonstrating that the South American catfish has the potential to feed on wastes without negative impacts on development, with a temperature of $16-18{ }^{\circ} \mathrm{C}$. Therefore, substantial biomass of high-value fish can be produced with the wastes of trout culture. In the proportion of $50 \%$ of South American catfish, total feed conversion was increased by about $21 \%$ when compared with trout monoculture, suggesting that the catfish in this case ingested less feces and more leftover diet.

The trout showed higher growth when reared in polyculture. This result may be due to the low trout density in polyculture tanks. In addition, this also indicates that South American catfish juveniles did not affect trout growth. Fish growth of one species has been shown to be higher in lower densities even when there are other species in the same pond (Uddin et al. 2007). For the rohu labeo (Labeo rohita), polyculture with the common carp (Cyprinus carpio) also improved the weight gain when compared to the monoculture (Rahman et al. 2006). Similar results were observed for the paddlefish (Polyodon spathula) in polyculture with the channel catfish and with the rainbow trout (Mims and Clark 1991).

South American catfish adapted well to polyculture with the trout, showing no conflicts that could result in high mortality. There was also no effect of the proportion of fish on the growth 
of South American catfish. For channel catfish, growth was lower in polyculture with trout (Tidwell and Mims 1990). In the present study, the same performance of South American catfish in monoculture and in polyculture indicates that trout did not negatively affect the catfish. However, the feed conversion of South American catfish in monoculture obtained in the present study was lower than that obtained by other authors for this species (Meyer and Fracalossi 2004; Salhi et al. 2004). This result is probably due to the use of a diet formulated for trout and not for catfish in the present study. In addition, a low temperature range may have impaired feed conversion and growth of the South American catfish. The best temperature for South American catfish culture is 22 to $28{ }^{\circ} \mathrm{C}$ (Piedras et al. 2004), although the species tolerates temperatures as low as $15{ }^{\circ} \mathrm{C}$ (Gomes et al. 2000). The mean temperature during the experiment was $17^{\circ} \mathrm{C}$. The South American catfish has shown reduced growth and increased feed conversion in temperatures below $23{ }^{\circ} \mathrm{C}$ (Piedras et al. 2004).

The data obtained for the feed conversion ratio confirms that polyculture of trout with South American catfish can improve the sustainability of trout production. Further studies are needed to show the technical and economic feasibility of the polyculture during advanced stages of the grow-out phase. South American catfish introduced into the culture while maintaining the normal density of trout should be evaluated. The additional production of fish with the same volume of water and diet is a strategy towards more sustainable aquaculture (Uddin et al. 2007; Costa et al. 2013).

\section{Conclusion}

Rainbow trout and South American catfish are compatible species for farming together in the first phase of their development. The different space occupied by those species inside tanks probably prevents competition or agonistic behavior. Catfish eat the non-ingested leftover diet from the trout and probably trout feces, which increases sustainability. Further research should be conducted to determine the best proportion among the species and if the benefits of polyculture observed in the present study are maintained during the final phases of grow-out culture.

\section{References}

Beem MD, Gebhart GE (1988) Winter polyculture of channel catfish and rainbow trout in cages. The. Prog Fish Cult 50(1):49-51. https://doi.org/10.1577/1548-8640(1988)050<0049:WPOCCA >2.3.CO;2

Booth AM, Allan LG, Smith WR (2000) Effects of grinding, steam conditioning and extrusion of a practical diet on digestibility and weight gain of silver perch, Bidyanus bidyanus. Aquaculture 182(3-4):287-299. https://doi.org/10.1016/S0044-8486(99)00261-6

Boyd CE, Tucker CS (1998) Pond aquaculture water quality management. Springer Science/Business Media, New York, p 699. https://doi.org/10.1007/978-1-4615-5407-3

Costa LCO, Xavier JAA, Neves LFM, Azambuja AMV, Wasielesky Junior W, Figueiredo MRC (2013) Polyculture of Litopenaeus vannamei shrimp and Mugil platanus mullet in earthen ponds. R Bras Zootec 42(9):605-611. https://doi.org/10.1590/S1516-35982013000900001

Eaton AD (2005) American Public Health Association, American Water Works Association, Water Environment Federation, standard methods for the examination of water and wastewater, 21st edn. Centennial ed, Washington

Fishbase (2017) Rhamdia quelen (Quoy, Gaimard 1824) bagre da America do Sul Available via http://wwwfishbasese/summary/Rhamdia-quelenhtml Cited 24 Mar 2017 
Gomes LC, Golombieski JI, Gomes ARC, Baldisserotto B (2000) Biologia do jundiá Rhamdia quelen (Teleostei, Pimelodidae). Ciênc Rural 30(1):179-185. https://doi.org/10.1590/S0103-84782000000100029

MacIntyre CM, Ellis T, North BP, Turnbill JF (2008) The influences of water quality on the welfare of farmed rainbow trout: a review. In: Branson EJ (ed) Fish welfare. Blackwell, Oxford, pp 150-172

Meyer G, Fracalossi DM (2004) Protein requirement of jundia fingerlings, Rhamdia quelen, at two dietary energy concentrations. Aquaculture 240(1-4):331-343. https://doi.org/10.1016/j.aquaculture.2004.01.034

Mims SD, Clark JA (1991) Overwintering paddlefish in monoculture and in polyculture with channel catfish and rainbow trout. J Appl Aquac 1(1):95-101. https://doi.org/10.1300/J028v01n01_08

Piedras SRN, Moraes PRR, Pouey JLOF (2004) Crescimento de juvenis de jundiá (Rhamdia quelen), de acordo com a temperatura da água. B Inst Pesca 30:177-182

Rahman MM, Verdegem MCJ, Nagelkerke LAJ, Wahab MA, Milstein A, Verreth JAJ (2006) Growth, production and food preference of rohu Labeo rohita (H.) in monoculture and in polyculture with common carp Cyprinus carpio (L.) under fed and non-fed ponds. Aquaculture 257(1-4):359-372. https://doi.org/10.1016/j. aquaculture.2006.03.020

Salhi M, Bessonart M, Chediak G, Bellagamba M, Carnevia D (2004) Growth, feed utilization and body composition of black catfish, Rhamdia quelen, fry fed diets containing different protein and energy levels. Aquaculture 231(1-4):435-444. https://doi.org/10.1016/j.aquaculture.2003.08.006

Tidwell AJ, Mims SD (1990) Winter polyculture of rainbow trout and fingerling channel catfish. Aquac Res 52: 105-108

Uddin M, Rahman MS, Azim EM, Wahab AM, Verdegem JCM, Verreth JAJ (2007) Effects of stocking density on production and economics of Nile tilapia (Oreochromis niloticus) and freshwater prawn (Machrobrachium rosenbergii) polyculture in periphyton-based systems. Aquac Res 38(16):1759-1769. https://doi.org/10.1111/j.1365-2109.2007.01837.x

Valladão GMR, Gallani SU, Pilarski F (2016) South America fish for continental aquaculture. Reviews in Aquaculture, Early view. https://doi.org/10.1111/raq.12164 